\title{
Engineered strains of Streptococcus macedonicus towards an osmotic stress resistant phenotype retain their ability to produce the bacteriocin macedocin under hyperosmotic conditions
}

\author{
Rania Anastasiou ${ }^{a}$, Gonzalez Van Driessche ${ }^{\mathrm{b}}$, Effrossyni Boutou ${ }^{\mathrm{c}}$, Maria Kazou ${ }^{\mathrm{a}}$, \\ Voula Alexandraki ${ }^{a}$, Constantinos E. Vorgias ${ }^{c}$, Bart Devreese ${ }^{\mathrm{b}}$, Effie Tsakalidou ${ }^{\mathrm{a}}$, \\ Konstantinos Papadimitriou ${ }^{\mathrm{a}, \mathrm{c}, *}$ \\ a Laboratory of Dairy Research, Department of Food Science and Human Nutrition, Agricultural University of Athens, Iera Odos 75, 11855 Athens, Greece \\ ${ }^{\mathrm{b}}$ Laboratory for Protein Biochemistry and Biomolecular Engineering, Ghent University, K.L. Ledeganckstraat 35, 9000 Ghent, Belgium \\ c Department of Biochemistry and Molecular Biology, Faculty of Biology, National and Kapodistrian University of Athens, Panepistimioupolis-Zographou, \\ 15784 Athens, Greece
}

\section{A R T I C L E I N F O}

\section{Article history:}

Received 12 July 2015

Received in revised form 17 August 2015

Accepted 20 August 2015

Available online 28 August 2015

\section{Keywords:}

Streptococcus

Clostridium

Osmotic

Stress

Mutants

Bacteriocin

\begin{abstract}
A B S T R A C T
Streptococcus macedonicus ACA-DC 198 produces the bacteriocin macedocin in milk only under low $\mathrm{NaCl}$ concentrations $(<1.0 \% \mathrm{w} / \mathrm{v})$. The thermosensitive plasmid pGh9:ISS1 was employed to generate osmotic stress resistant (osmr) mutants of S. macedonicus. Three osmr mutants showing integration of the vector in unique chromosomal sites were identified and the disrupted loci were characterized. Interestingly, the mutants were able to grow and to produce macedocin at considerably higher concentrations of $\mathrm{NaCl}$ compared to the wild-type (up to $4.0 \% \mathrm{w} / \mathrm{v}$ ). The production of macedocin under hyperosmotic conditions solely by the osmr mutants was validated by the well diffusion assay and by mass spectrometry analysis. RT-PCR experiments demonstrated that the macedocin biosynthetic regulon was transcribed at high salt concentrations only in the mutants. Mutant osmr3, the most robust mutant, was converted in its markerless derivative (osmr3f). Co-culture of $\mathrm{S}$. macedonicus with spores of Clostridium tyrobutyricum in milk demonstrated that only the osmr3f mutant and not the wild-type inhibited the growth of the spores under hyperosmotic conditions (i.e., $2.5 \% \mathrm{w} / \mathrm{v} \mathrm{NaCl}$ ) due to the production of macedocin. Our study shows how genetic manipulation of a strain towards a stress resistant phenotype could improve bacteriocin production under conditions of the same stress.
\end{abstract}

(c) 2015 Elsevier B.V. All rights reserved.

\section{Introduction}

Lactic acid bacteria (LAB) include the key bacterial species used in food fermentations. One of their most important properties recognized over the past decades is the ability to produce bacteriocins (Beshkova and Frengova, 2012; Cotter et al., 2005). The benign nature of food related LAB makes their bacteriocins appealing antimicrobials to be used against food spoilage and foodborne pathogens. Nisin and pediocin are approved food additives, while the application of several other bacteriocins in food processing has also been reported in the bibliography (Cotter et al., 2005). However, the direct addition of bacteriocins in food matrices has sometimes proved to be problematic for a number of reasons

\footnotetext{
* Corresponding author. Fax: +30 2105294672.

E-mail address: kpapadimitriou@aua.gr (K. Papadimitriou).
}

(Khan et al., 2010). For example, bacteriocins may have solubility issues in the food environment, they may be sequestered by different food ingredients and they may be susceptible to proteolytic enzymes present in foods. In addition, microorganisms in the food ecosystem may be naturally resistant to bacteriocins. Furthermore, large scale purification of bacteriocins may be a daunting task (Carolissen-Mackay et al., 1997). In practice, the in situ production of bacteriocins by the producer strain directly into the food matrix is preferred (Beshkova and Frengova, 2012). Several LAB strains have been suggested that can be used as bioprotective starters or adjuncts. Nevertheless, this approach is not without weaknesses either. The multiple stresses applied during food processing and storage may negatively influence the production of bacteriocins due to their effect on the physiology of the producer strain.

Streptococcus macedonicus ACA-DC 198 produces the bacteriocin macedocin that inhibits the growth of important spoilage or pathogen microorganisms of cheese (e.g., C. tyrobutyricum, Clostrid- 
ium perfringens, Brochothrix sp. and Bacillus sp.) and for this reason it was suggested that the strain could be used as a protective adjunct (Anastasiou et al., 2009; Anastasiou et al., 2007; Georgalaki et al., 2002; Van den Berghe et al., 2006). Macedocin is a lantibiotic of the lacticin 481 group and the gene cluster responsible for its biosynthesis ( $m c d$ ) has been described (Papadelli et al., 2007). The $m c d$ regulon consists of two putative operons, the $m c d A A ́ \times A 1 M T F E G$ encoding the structural genes of macedocin along with the maturation, transport and immunity functions, as well as the $m c d R K$ coding for the two component system (TCS) regulating the transcription of macedocin. It has been previously established that the optimum temperature for macedocin production is far below the optimum for growth (i.e., $20-25^{\circ} \mathrm{C}$ vs. $42.3^{\circ} \mathrm{C}$ ) (Van den Berghe et al., 2006). Specific macedocin production is maximal at $\mathrm{pH} 6.0$, slightly more acidic than $\mathrm{pH} 6.4$ that is optimal for growth, while the peptide is not produced at $\mathrm{NaCl}$ concentrations of 2.0 or $4.0 \%$ (w/v) (Poirazi et al., 2007; Van den Berghe et al., 2006). In this study, we investigated the effect of hyperosmotic stress on the growth of S. macedonicus ACA-DC 198 and on the production of macedocin. We employed S. macedonicus strain ACA-DC 198 whose genome was recently sequenced (Papadimitriou et al., 2014; Papadimitriou et al., 2012). We performed a genetic screen using the thermosensitive vector pGh9:ISS1 (Maguin et al., 1996) to generate osmotic resistant mutants (osmr) of $S$. macedonicus for the first time. The osmr mutants were characterized and their ability to synthesize macedocin in high $\mathrm{NaCl}$ concentrations was assessed. To the best of our knowledge this is the first report showing how genetically acquired resistance to a stress can favor bacteriocin production under conditions of the same stress.

\section{Materials and methods}

\subsection{Bacterial strains and growth conditions}

S. macedonicus ACA-DC 198 was grown at 30 or $42^{\circ} \mathrm{C}$ in MRS medium (Oxoid Ltd., Basingstoke, Hampshire, UK) supplemented with $200 \mathrm{mM}$ morpholinepropanesulfonic acid (MOPS, Sigma, St. Lewis, MO) and adjusted to pH 7.0 (MRS-MOPS), as previously described (Papadimitriou et al., 2007). For bacteriocin production, the strain was grown at $42{ }^{\circ} \mathrm{C}$ in skimmed milk $(10 \% \mathrm{w} / \mathrm{v}$, Oxoid Ltd.) with $0.3 \%(\mathrm{w} / \mathrm{v})$ yeast extract (Biokar, Beauvais, FR). Skimmed milk supplemented with yeast extract was sterilized by autoclaving at $121^{\circ} \mathrm{C}$ for $5 \mathrm{~min}$ according to the instructions of the manufacturer. Lactococcus lactis subsp. lactis LMG $6890^{\mathrm{T}}$ was grown in M17 broth (Biokar) at $30^{\circ} \mathrm{C}$ for $18 \mathrm{~h}$, while C. tyrobutyricum LMG $1285^{\mathrm{T}}$ was grown in Reinforced Clostridial Medium broth (RCM, Biokar) at $37^{\circ} \mathrm{C}$ for $48 \mathrm{~h}$ (inoculum of $1 \%, \mathrm{v} / \mathrm{v}$ ) under anaerobic conditions (GasPak ${ }^{\mathrm{TM}}$ EZ Anaerobe Container System, BD Diagnostics, MD, USA). Escherichia coli EC101 was the host for plasmid rescue experiments and was grown in Luria-Bertani (LB) medium in the presence of erythromycin $(160 \mu \mathrm{g} / \mathrm{ml})$. E. coli EC101 and the EC101 strain containing pGh9:ISS1 were kindly provided by Prof. Ezio Ricca (Department of Biology, Federico II University, Naples, Italy).

Media for hyperosmotic treatment were prepared as follows: In the case of the synthetic medium, $\mathrm{NaCl}$ was directly dissolved in MRS-MOPS so as to reach concentrations ranging from $0.5-4.0 \%$ $(\mathrm{w} / \mathrm{v})$ prior to sterilization. In the case of skimmed milk, the same concentrations were achieved by aseptically adding the appropriate volume from a sterile $30 \%(\mathrm{w} / \mathrm{v}) \mathrm{NaCl}$ solution in pre-sterilized milk media. The acidification of milk during the growth of $S$. macedonicus ACA-DC 198 in milk was recorded using a Hanna HI 98,249 $\mathrm{pH}$ meter (Woonsocket, RI, USA).

\subsection{Transformation of Streptococcus macedonicus cells with pGh9:ISS1}

To the best of our knowledge, electrotransformation of S. macedonicus has not been attempted before. The strain proved quite resistant to electroporation with pGh9:ISS1. According to recent in silico genomic evidence $S$. macedonicus ACA-DC 198 seems to be able to degrade foreign DNA as it is a member of the Streptococcus bovis/Streptococcus equinus complex that carries 7 restriction modification systems and a clustered regularly interspaced short palindromic repeats (CRISPR) system (Papadimitriou et al., 2014). We have attempted to clone additional plasmids in S. macedonicus e.g., the pORI198 that carries the origin of replication of a native $S$. macedonicus plasmid with no success (Papadimitriou et al., 2015). A procedure yielding some tens of transformants per $\mu \mathrm{g}$ of the pGh9:ISS1 plasmid was developed relying partly on the Holo and Nes protocol (Holo and Nes, 1989) without growing the strain in osmotically stabilized with glycine medium. In detail, early logarithmic phase cells $\left(\mathrm{OD}_{620} \sim 0.3-0.4\right)$ grown in MRS-MOPS $\left(37^{\circ} \mathrm{C}\right)$ were harvested by centrifugation at $8000 \mathrm{rpm}$ for $5 \mathrm{~min}$ and washed twice with ice-cold buffer containing $0.5 \mathrm{M}$ sucrose and $10 \%(\mathrm{v} / \mathrm{v})$ glycerol. Cells were re-suspended in the same buffer at a 20 -fold concentration and kept on ice for no more than $30 \mathrm{~min}$. Fortymicroliter aliquots of competent cells were mixed with 1-5 $\mu \mathrm{l}$ of DNA dissolved in $5 \mathrm{mM}$ Tris/ $\mathrm{HCl} \mathrm{pH}$ 8.5. Electroporation was performed using the MicroPulser ${ }^{\mathrm{TM}}$ electroporator (Bio-Rad Laboratories, Hercules, CA, USA) at $2.5 \mathrm{kV}$, while resistance was set at $200 \mathrm{ohms}$ and capacitance at $25 \mu \mathrm{F}$ in cuvettes of $0.2 \mathrm{~cm}$ electrode gap width (O'Sullivan and Fitzgerald, 1999). Immediately after electroporation, the suspension was mixed with $960 \mu \mathrm{l}$ of MRS-MOPS containing $0.5 \mathrm{M}$ sucrose, $20 \mathrm{mM} \mathrm{MgCl}_{2}$ and $2 \mathrm{mM} \mathrm{CaCl}_{2}$. The cells were incubated at $30^{\circ} \mathrm{C}$ for $1 \mathrm{~h}$. Serial dilutions were plated on MRS-MOPS agar $(1.5 \% \mathrm{w} / \mathrm{v})$ containing $1 \mu \mathrm{g} / \mathrm{ml}$ erythromycin and colonies were selected after $48 \mathrm{~h}$ at $30^{\circ} \mathrm{C}$. Even with this protocol our transformation efficiency was very low and the success of the procedure erratic. Inability to efficiently transform "wild" LAB strains is not an uncommon event.

\subsection{Isolation of Streptococcus macedonicus osmr mutants generated using the pGh9:ISS1 plasmid and subsequent characterization}

pGh9:ISS1 is a thermosensitive replicon that at low temperatures (permissive) can replicate in the cytosol of LAB like L. lactis, while shifting the conditions of the culture to higher temperatures (restrictive) initiates the integration of the plasmid in the chromosome of the host (Maguin et al., 1996). In general, the presence of the ISS1 element in the vector supports its randomized integration in the genome. Both permissive $\left(30^{\circ} \mathrm{C}\right)$ and restrictive $\left(42^{\circ} \mathrm{C}\right)$ temperatures of the transposition assay in $S$. macedonicus were chosen according to the relevant literature for L. lactis and/or Streptococcus thermophilus (Baccigalupi et al., 2000; Maguin et al., 1996; Thibessard et al., 2002). The final restrictive temperature for the selection of the osmr mutants was determined in control experiments with the wild-type plated on MRS-MOPS plates in which the $\mathrm{NaCl}$ content was kept constant at $2.0 \%(\mathrm{w} / \mathrm{v})$ and the incubation temperature was increased until cell death occurred at a rate of $\sim 10^{-8}-10^{-9}$ within $72 \mathrm{~h}$. This temperature was determined to be $46^{\circ} \mathrm{C}$. It should be mentioned that $46^{\circ} \mathrm{C}$ was not lethal for the $S$. macedonicus wild-type in the absence of $\mathrm{NaCl}$. The isolation of osmotic tolerant S. macedonicus mutants (osmr) relied basically on similar protocols described previously (Baccigalupi et al., 2000; Maguin et al., 1996; Thibessard et al., 2002), adapted for the particular strain and the particular stress. In detail, S. macedonicus transformed with pGh9:ISS1 was grown overnight in MRS-MOPS with erythromycin $(1 \mu \mathrm{g} / \mathrm{ml})$. Fifty microliters were used to inoc- 
ulate a $5 \mathrm{ml}$ MRS-MOPS culture without erythromycin that was kept at $30^{\circ} \mathrm{C}$ for $1.5 \mathrm{~h}$ and then shifted to $42^{\circ} \mathrm{C}$ for another $1.5 \mathrm{~h}$ to start the integration process of the vector into the bacterium's chromosome. One hundred-microliter aliquots were then plated on MRS-MOPS with $2.0 \%(\mathrm{w} / \mathrm{v}) \mathrm{NaCl}$ and $1 \mu \mathrm{g} / \mathrm{ml}$ erythromycin. The plates were incubated at $46^{\circ} \mathrm{C}$ and colonies appearing after $72 \mathrm{~h}$ were picked. These colonies were grown in MRS-MOPS with $1 \mu \mathrm{g} / \mathrm{ml}$ erythromycin, spotted on MRS-MOPS 2.5\% (w/v) $\mathrm{NaCl}$ without erythromycin along with the wild-type and incubated at $42{ }^{\circ} \mathrm{C}$ to verify their mutant phenotype due to pGh9:ISS1 integration. The efficiency of the pGh9:ISS1 transposition in S. macedonicus was assessed in parallel to the aforementioned experiment by plating after the induction of transposition S. macedonicus cells in MRS-MOPS with or without erythromycin $(1 \mu \mathrm{g} / \mathrm{ml})$ at $46^{\circ} \mathrm{C}$. The transposition efficiency was calculated as the ratio of the number of colonies growing on MRS-MOPS with erythromycin to the number of colonies growing on MRS-MOPS without erythromycin.

To assess integration of the pGh9:ISS1 in the chromosome of the osmr mutants we performed Southern blot analysis. In brief, $2 \mu \mathrm{g}$ of genomic DNA were isolated from the mutants, digested with EcoRI (New England Biolabs Inc., Ipswich, MA), resolved electrophoretically on a $1 \%(\mathrm{w} / \mathrm{v})$ agarose gel and transferred to a positively-charged nylon membrane (Roche Diagnostics $\mathrm{GmbH}$, Penzberg, Germany) as described previously (Sambrook et al., 1989). The probe used was a 987 bp fragment of the erythromycin resistance gene in the pGh9:ISS1 plasmid, amplified by PCR using primers ErmF/R (Table 1). The probe was labeled with the DIG DNA Labeling Mix (Roche Diagnostics GmbH, Mannheim, Germany) according to the manufacturer's instructions. Hybridization and immunological detection were performed as recommended by the supplier. To assess for tandem transposition in the chromosome of S. macedonicus the linearized pGh9:ISS1 plasmid was also run on the gel as a control.

For the characterization of the vector-chromosome junctions, plasmid rescue experiments were performed basically as described previously (Baccigalupi et al., 2000). In brief, genomic DNA was digested by an enzyme cutting within the pGh9:ISS1 only once, e.g., EcoRI or HindIII (New England Biolabs). After circularization by self-ligation with T4 DNA ligase (New England Biolabs), DNA was concentrated with the NucleoSpin Plasmid spin columns (Macherey Nagel, Düren, Germany) and transformed in E. coli EC101 cells. Transformants were selected on LB medium supplemented with $160 \mu \mathrm{g} / \mathrm{ml}$ erythromycin. Colony PCR was performed in order to discriminate between rescued plasmids containing pGh9:ISS1chromosomal junction to blank pGh9:ISS1 plasmids generated due to tandem transposition. The primers used for the colony PCR were the pGHF/pGER (Table 1). Rescued plasmids were sequenced to identify chromosomal flanking regions using primers pGh9 $\mathrm{M}$ and pGh9H depending on whether genomic DNA was digested with EcoRI or HindIII, respectively. The sequence of the primers is presented in Table 1. Plasmid-chromosome junctions were analyzed with Blastn (Altschul et al., 1997) against the sequenced genome of S. macedonicus ACA-DC 198 (accession number HE613569.1).

\subsection{Assessment of bacteriocin production}

The ability of $S$. macedonicus wild-type or osmr mutants to produce macedocin under iso- and hyperosmotic conditions was assessed by the well diffusion assay (WDA), as described previously (Georgalaki et al., 2002). Briefly, $50 \mu$ l of cleared supernatant adjusted to $\mathrm{pH} 6.5$ with $1 \mathrm{~N} \mathrm{NaOH}$ were used to fill the wells on a M17 plate seeded with L. lactis LMG $6890^{\mathrm{T}}$ that served as the indicator strain. The plate was incubated at $30^{\circ} \mathrm{C}$ and inhibition zones were measured after $16 \mathrm{~h}$.

\subsection{Reverse Transcription ( $R T)-P C R$ experiments}

Total RNA was isolated from logarithmically growing S. macedonicus wild-type or osmr mutant cells in skimmed milk for $7 \mathrm{~h}$ containing 0 or $2.0 \%(\mathrm{w} / \mathrm{v}) \mathrm{NaCl}$ using the RNeasy Mini Kit and the RNAprotect Cell Reagent (QIAGEN Inc., Hilden, DE). After treatment with DNase (RNase-Free DNase Set, Qiagen Inc.), the quantity and quality of the extracted RNA was assessed spectrophotometrically $\left(A_{260 / 280}\right)$ and its integrity was checked electrophoretically. PCR was performed directly on the isolated RNA with the primer pairs that were used subsequently for the RT-PCR to validate total degradation of DNA in the samples (data not shown). One hundred nanograms of RNA were used for cDNA synthesis with the Superscript reverse transcriptase (Invitrogen ${ }^{\mathrm{TM}}$, Carlsbad, CA, USA) that was further amplified with the DyNAzyme ${ }^{\mathrm{TM}}$ EXT DNA Polymerase (Thermo Scientific, Vantaa, FI) for no more than 25 cycles. For the RT-PCR reactions targeting the $m c d A A \times A 1 M T F E G$ operon of macedocin we used two pairs of primers, the pFA/pRA $\times$ and the pF5/pR5 specific for the mcdAAí and the mcdMT, respectively. Primers mcdKR-F/mcdKR-R were specific for the mcdRK operon, while primers 16 SMac-F/16SMac-R were specific for the 16S RNA subunit. The sequence of the primers used in this study is presented in Table 1.

\subsection{Mass spectrometry (MS) analysis}

Apart from the S. macedonicus wild-type we chose to assess the ability of osmr3 mutant to produce the bacteriocin macedocin in milk in the presence or absence of $2.5 \%(\mathrm{w} / \mathrm{v}) \mathrm{NaCl}$ in three independent experiments. In detail, the wild-type and the osmr3 mutant were subcultured once in MRS-MOPS without erythromycin at $42{ }^{\circ} \mathrm{C}$. Five milliliters of sterile skimmed milk $(10 \%$ $\mathrm{w} / \mathrm{v})$ supplemented with $0.3 \%(\mathrm{w} / \mathrm{v})$ yeast extract with or without $2.5 \%(\mathrm{w} / \mathrm{v}) \mathrm{NaCl}$, were inoculated with the wild-type or the osmr3 mutant ( $1 \% \mathrm{v} / \mathrm{v}$ inoculum). Cultures were incubated at $42^{\circ} \mathrm{C}$ overnight and then centrifuged at $10,000 \mathrm{rpm}$ for $10 \mathrm{~min}$ to collect the cleared supernatants. The $\mathrm{pH}$ of the supernatants was adjusted to 7.0 centrifuged again at $10,000 \mathrm{rpm}$ for $10 \mathrm{~min}$ to obtain the clear supernatants, sterilized through $0.22 \mu \mathrm{m}$ filters (Millipore Corp., Bedford, Massachusetts, US) and lyophilized.

For MS analysis the samples were solubilized in $10 \mathrm{ml}$ of Milli-Q grade water and $75 \mu \mathrm{l}$ of this solution were desalted (by pipetting 5' $15 \mu \mathrm{l}$ ) using a C4-Ziptip (Merck Millipore, Billerica, MA) according to the manufacturer's instructions. Final elution was performed using $2 \times 15 \mu \mathrm{l}$ of $50 \%(\mathrm{v} / \mathrm{v})$ acetonitrile/0.1\% (v/v) formic acid in water. The eluates were pooled and $2 \mu \mathrm{l}$ of this desalted solution were mixed with $2 \mu \mathrm{l}$ of a $5.7 \mathrm{mg} / \mathrm{ml}$ solution of $\alpha$-cyano hydroxycinnamic acid (Sigma) in 50\% (v/v) acetonitrile/0.1\% (v/v) formic acid. One $\mu \mathrm{l}$ was spotted on a Maldi-plate and allowed to dry by air. The sample was then analyzed using a 4800 MALDI TOF-TOF mass spectrometer (Sciex, Framingham, MA) operated in linear and reflectron mode, respectively. This mass spectrometer is equipped with a Nd-YAG laser operating at a frequency of $200 \mathrm{~Hz}$. For linear mode, the source voltage was kept at $3700 \mathrm{~V}$. In total 2000 shots were accumulated to obtain a spectrum. In reflector mode, the source voltage was $4500 \mathrm{~V}$, and 3000 shots were accumulated to obtain a spectrum. The mass spectrometer was externally calibrated with a mixture of peptides (CALMIX-1, Applied Biosystems, Foster City, CA) following the instructions of the manufacturer.

\subsection{Excision of the pGh9:ISS1 vector from the chromosome of osmr3}

The mutant osmr3 was selected for its conversion into its markerless derivative. The strain was subcultured twice and streaked on MRS-MOPS at non restricting conditions for plasmid excision (i.e., 
Table 1

Primers used in this study.

\begin{tabular}{|c|c|c|}
\hline Primer (gene target) & Sequence ( $5^{\prime}$ to $3^{\prime}$ ) & Reference \\
\hline $\mathrm{pFA}(\operatorname{mcd} A)$ & ATTTCTTGCTACATGTTGCTCATAA & Georgalaki et al., (2010) \\
\hline $\mathrm{pRA} \times(m c d A \hat{i})$ & CATATTAGACACTTAGTCATCC & Georgalaki et al., (2010) \\
\hline pF5 (mcdM) & GTTTAGAGAATGGATGGATGTGC & Papadelli et al., (2007) \\
\hline pR5 $(\operatorname{mcd} T)$ & CAATAGCGGGATCTACAATCG & Papadelli et al., (2007) \\
\hline$m c d K R-\mathrm{F}(\operatorname{mcdR})$ & ATGATGTTGGAGGAAACTG & This study \\
\hline$m c d K R-\mathrm{R}(m c d K)$ & AATCAAGCCCTTCTAAACC & This study \\
\hline ErmF & GGAAACGTAAAAGAAGTTATGGA & This study \\
\hline ErmR & GGGACCTCTTTAGCTCCTTGG & This study \\
\hline pGHF & TTTCCCAGTCACGACG & This study \\
\hline pGER & GGTATACTACTGACAGCTTCC & This study \\
\hline pGh9M & ATAGTTCATTGATATATC & This study \\
\hline pGh9H & CTACTGAGATTAAGGTC & This study \\
\hline 16SMac-F (16S RNA subunit) & GCAGTGGCTTAACCATTGTTCG & This study \\
\hline 16SMac-R (16S RNA subunit) & GCCTAACACCTAGCACTCATCG & This study \\
\hline
\end{tabular}

in the absence of erythromycin, $30^{\circ} \mathrm{C}$ ). Insertion of pGh9:ISS1 vector takes place after duplication of the ISS1 element. Accordingly, excision of the plasmid during growth at permissive temperature leaves behind one of the two ISS1 elements leading to conservation of the mutated phenotype due to maintenance of the disruption of the genetic locus. Ten colonies were picked and checked for the retention of the osmr phenotype and the loss of resistance to erythromycin. One colony that satisfied both conditions was selected and it was assigned as osmr3f.

\subsection{Co-culture of Streptococcus macedonicus wild-type or} osmr3f mutant with Clostridium tyrobutyricum spores in milk

C. tyrobutyricum LMG $1285^{\mathrm{T}}$ spores were prepared basically as described previously (Anastasiou et al., 2009). C. tyrobutyricum was grown in RCM for 8 days at $37^{\circ} \mathrm{C}$ under anaerobic conditions. Spores and vegetative cells were collected at $5000 \mathrm{rpm}$ for $15 \mathrm{~min}$ and washed twice with sterile distilled water. The pellet was resuspended in sterile $10 \%(\mathrm{w} / \mathrm{v})$ skimmed milk, aliquoted and stored at $-20^{\circ} \mathrm{C}$. The spore titer in aliquots was determined after heat inactivation of vegetative cells at $75^{\circ} \mathrm{C}$ for $15 \mathrm{~min}$ and plating on RCM agar. This heat treatment also served for the activation of the clostridial spores (Anastasiou et al., 2009).

For the co-culture experiments, wild-type or osmr3f $S$. macedonicus cells were inoculated $(1 \% \mathrm{v} / \mathrm{v}$ inoculum from an overnight culture) along with $\sim 10^{4} / \mathrm{ml}$ heat-activated $C$. tyrobutyricum spores in $5 \mathrm{ml}$ skimmed milk with 0 or $2.5 \%(\mathrm{w} / \mathrm{v}) \mathrm{NaCl}$. The fact that all samples including controls were incubated under static conditions having the same $\mathrm{O}_{2}$ availability makes the results of this experiment independent of this parameter. Samples were taken after $24 \mathrm{~h}$ and the $C$. tyrobutyricum enumeration was performed with the most probable number (MPN) method in BBMB medium (Biokar) (Anastasiou et al., 2009). Incubation lasted 6 days at $37^{\circ} \mathrm{C}$ without heat-treatment in order to enumerate both spores and vegetative cells. Appropriate mono-culture controls were included. The production of macedocin was also assessed in all cases with the WDA.

\section{Results}

\subsection{Effect of hyperosmotic conditions on the growth of} Streptococcus macedonicus and the production of macedocin

The effect of increasing $\mathrm{NaCl}$ concentrations on the growth of S. macedonicus in skimmed milk was assessed by following the decrease of $\mathrm{pH}$ (Fig. 1a). $\mathrm{NaCl}$ concentrations up to $1.5 \%(\mathrm{w} / \mathrm{v})$ did not seem to influence the ability of the bacterium to grow and to acidify its environment. A slight reduction of $S$. macedonicus growth rate and acidification capacity was observed at $2.0-3.0 \%(\mathrm{w} / \mathrm{v}) \mathrm{NaCl}$, while at concentrations above $3.0 \%(\mathrm{w} / \mathrm{v})$ growth practically ceased.

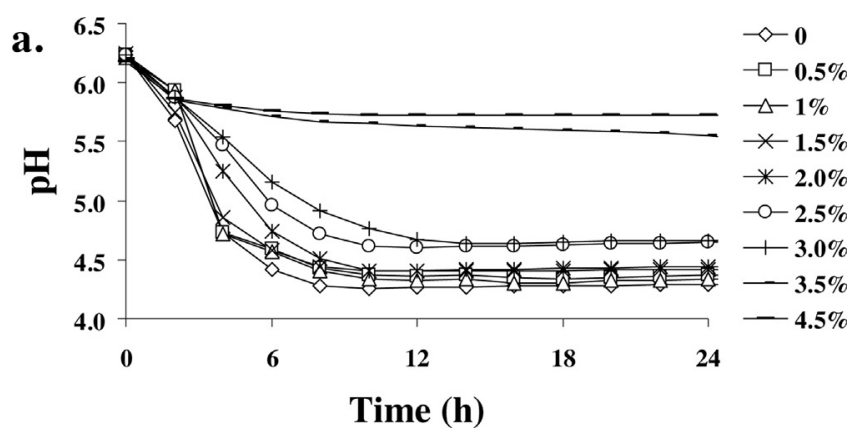

b.

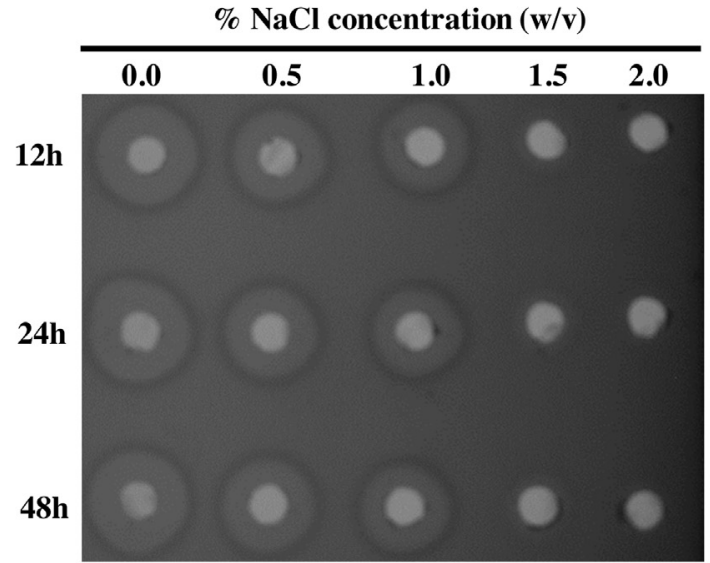

c.

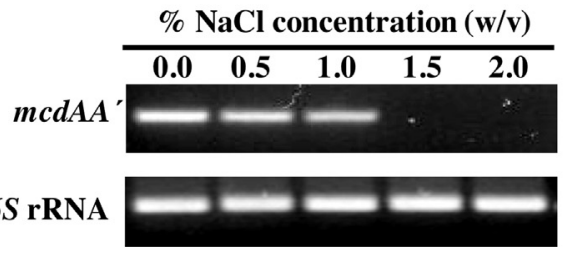

Fig. 1. Growth and bacteriocin production of S. macedonicus ACA-DC 198 unde hyperosmotic conditions in milk. Growth of S. macedonicus was recorded in triplicates through the drop of $\mathrm{pH}$ in sterile milk at increasing $\mathrm{NaCl}$ concentrations (a). Production of macedocin by $\mathrm{S}$. macedonicus during growth for 12, 24 and $48 \mathrm{~h}$ under hyperosmotic conditions in milk as estimated by the WDA (b). Expression of the $m c d A A \times$ structural genes of macedocin during growth under hyperosmotic conditions in milk as determined by RT-PCR (c). The 16S rRNA was used as the loading control. 
Interestingly, when macedocin's production was evaluated under the same conditions, it was found to gradually decline at $0-1.0 \%$ $(\mathrm{w} / \mathrm{v}) \mathrm{NaCl}$, before being abruptly stopped at higher concentrations of salt (Fig. 1b). The expression levels of the macedocin $\operatorname{mcdA}$ and $m c d A \times$ adjacent structural genes found in the mcd biosynthetic operon correlated well with the negative effect of $\mathrm{NaCl}$ on the production of the bacteriocin peptide (Fig. 1c). These findings clearly support that macedocin's biosynthesis is abrogated at $\mathrm{NaCl}$ concentrations much lower than those required to prevent growth of the producer strain.

\subsection{Isolation and characterization of Streptococcus macedonicus osmr mutants}

The thermosensitive vector pGh9:ISS1 was used to generate the osmr S. macedonicus mutants. The transposition efficiency of pGh9:ISS1 in S. macedonicus was $\sim 10^{-2}-10^{-3}$ which is in the same range to that reported for $S$. thermophilus (Thibessard et al., 2002). A combination of elevated temperature and mild osmotic stress was employed for the selection of the mutants. Experiments with the wild-type revealed that $46^{\circ} \mathrm{C}$ and $2.0 \%(\mathrm{w} / \mathrm{v}) \mathrm{NaCl}$ concentration in MRS-MOPS proved to be lethal for S. macedonicus. During the transposition $\sim 10^{7}-10^{8}$ cells were plated to select for mutants. Based on the transformation efficiency determined this corresponds to $>10^{4}$ mutants per plate. Mutant strains were directly selected on media with hyperosmotic conditions lethal for the wild-type. Thirteen colonies were picked but only nine of them were able to re-grow under hyperosmotic conditions (data not shown). From the nine osmr mutants only three were considered reliable for further investigation since pGh9:ISS1 was integrated in a unique locus in the chromosome of each mutant as revealed by Southern blot analysis (Fig. 2a and b). Furthermore, in silico analysis with the ISsaga tool (Varani et al., 2011) demonstrated the presence of several ISS1 sequences (of the IS6 family) in the genome of $S$. macedonicus ACADC 198. These findings support that transposition of pGh9:ISS1 in S. macedonicus may be influenced by the presence of these sequences generating insertional "hotspots". This hypothesis may also explain the fact that the majority of our mutants showed integration in multiple loci.

Plasmid rescue experiments were performed in order to identify the disrupted loci. As shown in Fig. 2b, all osmr mutants exhibited tandem transposition of pGh9:ISS1 making the cloning of chromosome-plasmid junctions challenging due to the high background of blank vectors during plasmid rescue (Fig. 2c). This is an additional indication that the use of the pGh9:ISS1 tool is problematic in S. macedonicus. Nevertheless, mutants osmr1, osmr2 and osmr3 were found disrupted in SMA_0533, SMA_1990 and SMA_1283, respectively. Sequence analysis of SMA_0533 and SMA_1990 revealed that they contain potential membrane spanning regions (data not shown). In fact, SMA_0533 is highly similar to proteins annotated as permeases in a number of streptococcal species. However, we could not find any experimental evidence supporting the actual function of these proteins. SMA_1283 is coding for an AroD 3-dehydroquinate dehydratase I potentially involved in the biosynthesis of aromatic amino acids. Further analysis is required to validate and explore the role of these mutations in the osmr phenotype.

\subsection{Streptococcus macedonicus $A C A-D C 198$ osmr mutants retain their ability to produce macedocin under hyperosmotic stress conditions}

The three osmr mutants were further studied for their ability to produce macedocin. Interestingly, osmr1 and osmr2 were able to produce macedocin when grown at $42^{\circ} \mathrm{C}$ and at concentrations as high as $3.0 \%(\mathrm{w} / \mathrm{v}) \mathrm{NaCl}$, while osmr3 proved to be more robust
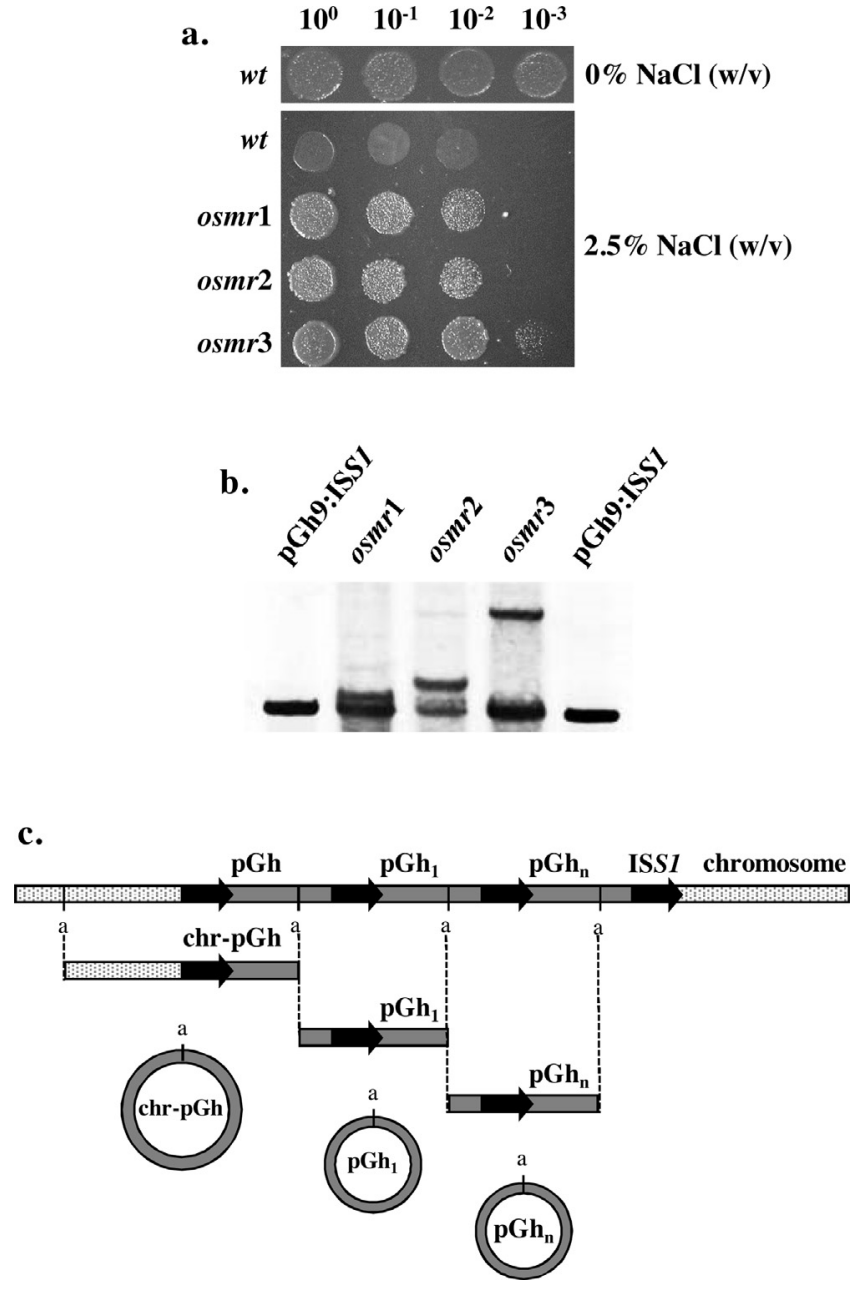

Fig. 2. Growth of the S. macedonicus wild-type and osmr mutants under iso- or hyperosmotic conditions (a). For each strain serial decimal dilutions were performed and $2 \mu \mathrm{l}$ of each dilution were spotted on MRS-MOPS agar, supplemented with $2.5 \%$ $(\mathrm{w} / \mathrm{v}) \mathrm{NaCl}$. As a positive control serial dilutions of the wild-type were spotted on MRS-MOPS agar without $\mathrm{NaCl}$. Integration of the pGh9:ISS1 in the osmr mutants as verified by Southern hybridization (b). The pGh9:ISS1 plasmid was used as a positive control and as a control for tandem transposition. The presence of a band of identical size to pGh9:ISS1 in all osmr mutants suggests that the vector was integrated in the chromosome of $S$. macedonicus through tandem transposition as shown schematically (c). The pGh9:ISS1 plasmid can integrate multiple times $(n)$ in the chromosome of the target microorganism. Digestion with an enzyme that cuts only once (e.g., EcoRI or HindIII) in the plasmid region may facilitate the release of the plasmidchromosome junction plus plasmid fragments $(n-1)$ that when circularized would result in "blank" pGh9:ISS1 plasmids.

producing macedocin even at $4.0 \%(\mathrm{w} / \mathrm{v}) \mathrm{NaCl}$ (Fig. 3a). In fact, initial experiments with randomly picked $S$. macedonicus strains in which transposition of pGh9:ISS1 had already occurred but they were not selected under hyperosmotic conditions (i.e., they were picked from MRS-MOPS plates with no salt resistant phenotype) exhibited an identical phenotype to that of the wild-type (data not shown). These results suggest that the genetically acquired stress resistance of the osmr mutants had a profound positive effect on the production of macedocin.

We performed MS analysis of milk derived supernatants supplemented with $2.5 \%(\mathrm{w} / \mathrm{v}) \mathrm{NaCl}$ or not for the wild-type and one of the osmr mutants (osmr3) (Fig. 4). A peak corresponding to the molecular mass of macedocin was identified in all samples deriving from milk without $\mathrm{NaCl}$. In contrast, in the samples deriving from milk with $2.5 \%(\mathrm{w} / \mathrm{v}) \mathrm{NaCl}$ the macedocin molecular mass peak was only detected in the samples of the osmr3 mutant but not of the wildtype. This data clearly corroborates with our WDA results showing 

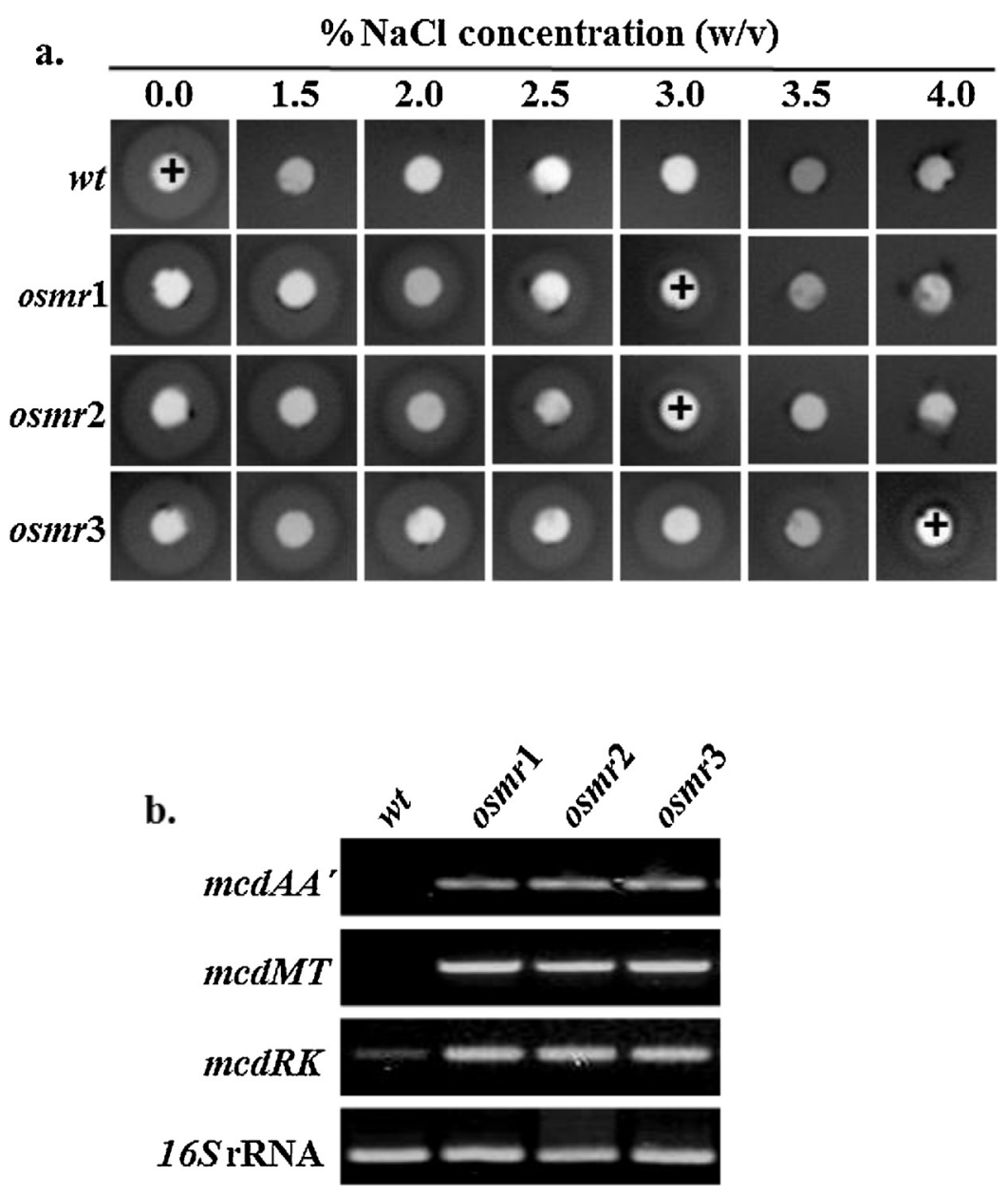

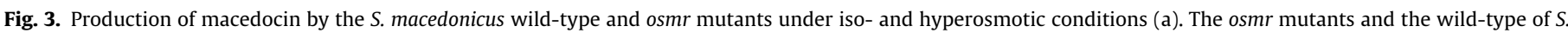

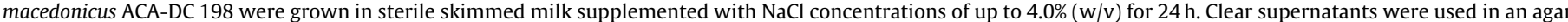

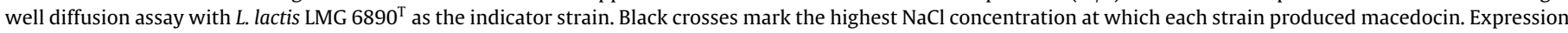

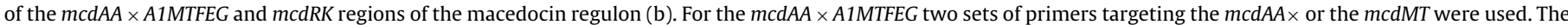
$16 \mathrm{~S}$ rRNA was used as the loading control.

antimicrobial activity of $S$. macedonicus hyperosmotic milk supernatants $(>1 \% \mathrm{w} / \mathrm{v} \mathrm{NaCl})$ against $L$. lactis only for the osmr mutants but not for the wild-type.

In order to investigate the reasons behind the abrogation of macedocin's production under hyperosmotic conditions, we studied the transcription of the mcd regulon in the wild-type as well as in the osmr mutants grown for $7 \mathrm{~h}$ in milk containing $2.0 \%$ (w/v) $\mathrm{NaCl}$ (Fig. 3b). Under the conditions tested all mutants retained the transcription of the entire $m c d$ regulon (i.e., of both the $m c d A A \times A 1 M T F E G$ and $m c d R K$ operons). In contrast, the wild-type exhibited minor transcription levels only for the $m c d R K$ operon. Our findings show that high $\mathrm{NaCl}$ concentrations result in the shutting down of the expression of the macedocin regulon in the wild-type. In contrast, the osmr phenotype abolishes the negative effect on the transcription of the $m c d$ regulon under hyperosmotic conditions.

3.4. Co-culture of Streptococcus macedonicus wild-type or osmr3f mutant with Clostridium tyrobutyricum spores in milk under iso-osmotic and hyperosmotic conditions

Since osmr3 mutant exhibited the most robust phenotype, it was converted into its markerless derivative osmr3f. The behavior of the osmr3f mutant regarding its salt resistance was the same to that of its parental strain (Fig. 5a). The ability of osmr3f to produce macedocin and consequently to inhibit $C$. tyrobutyricum spores was further tested in co-culture experiments. More specifically, the wild-type or osmr3f were cultured with $\sim 10^{4} / \mathrm{ml}$ heat-activated $C$. tyrobutyricum spores in skimmed milk supplemented or not with $2.5 \%(\mathrm{w} / \mathrm{v}) \mathrm{NaCl}$. Both the wild-type and osmr3f strongly inhibited the vegetation of $C$. tyrobutyricum spores (less than $0.5 \%$ spore survival) when grown in milk due to the production of macedocin (Fig. 5b). Under hyperosmotic conditions, the wild-type was not able to produce macedocin and thus vegetation of $C$. tyrobutyricum spores was observed. In contrast, osmr3f produced macedocin even at high $\mathrm{NaCl}$ concentrations, resulting in an inhibition of $C$. tyrobutyricum spore vegetation similar to that observed in milk without $\mathrm{NaCl}$ (Fig. 5b).

\section{Discussion}

Fermented foods rarely rely solely on the fermentation for safety and an extended shelf life. During food manufacturing, extreme physicochemical conditions are also employed, aiming to be bacteriostatic or bactericidal for spoilage bacteria and foodborne pathogens. LAB as starters or adjuncts have to be able to endure such treatments and to retain their viability at least until the end of the fermentation (Franz and Holzapfel, 2011). Nevertheless, even mild technological stresses may interfere with LAB metabolism, especially with biosynthetic pathways like the production of bacteriocins. Bacteria produce these peptides or proteins in an attempt 
a.

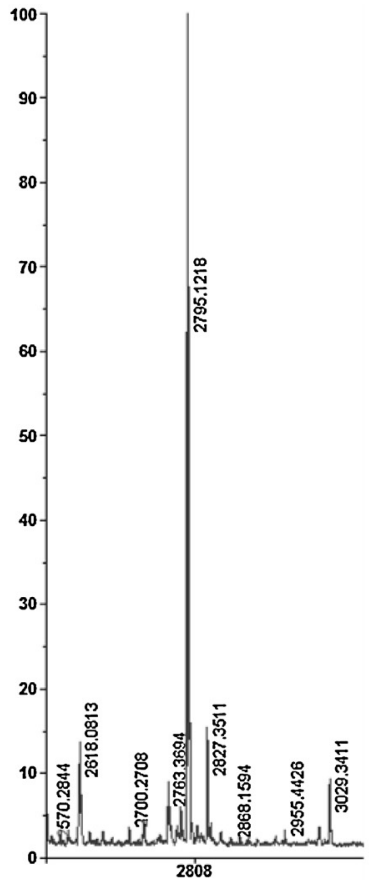

b.

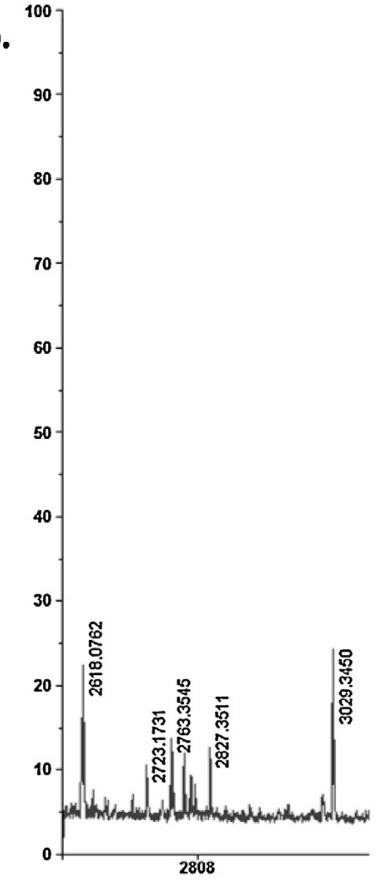

c.

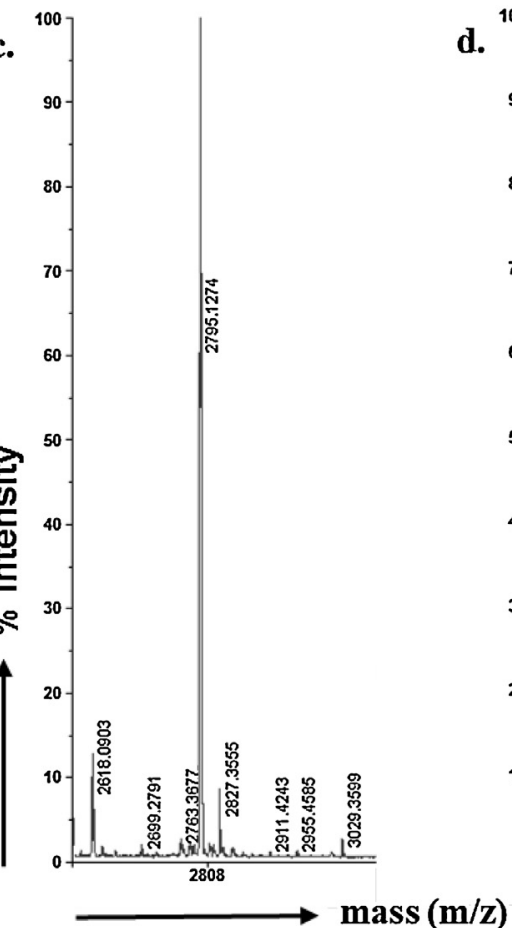

d.

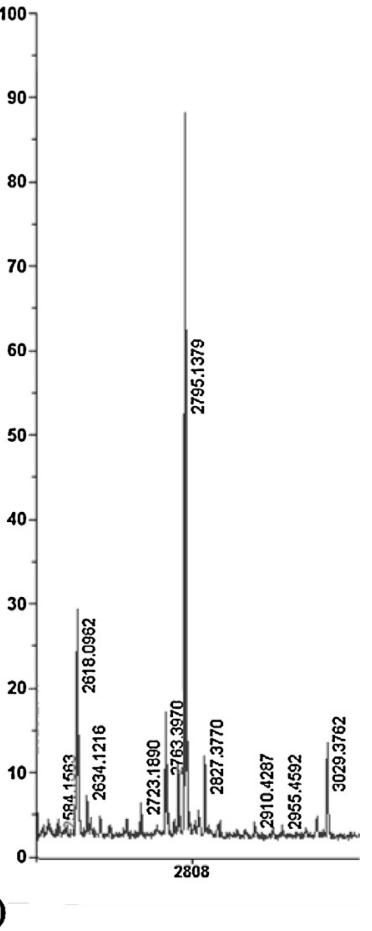

Fig. 4. Mass spectrometry (MS) analysis of $S$. macedonicus wild-type and osmr3 mutant. The peak that corresponds to the molecular mass of macedocin (2795 Da) was absent only in the $S$. macedonicus wild-type grown in milk supplemented with $2.5 \%(\mathrm{w} / \mathrm{v}$ ) $\mathrm{NaCl}$. Streptococcus macedonicus wild-type grown in milk containing $0 \%$ (a) or $2.5 \%(\mathrm{w} / \mathrm{v}) \mathrm{NaCl}(\mathrm{b})$. Osmr3 mutant grown in milk containing $0 \%$ (c) or $2.5 \%$ $(\mathrm{w} / \mathrm{v}) \mathrm{NaCl}(\mathrm{d})$. All experiments for the MS analysis were performed in triplicates.

to prevail in the biological warfare that takes place in their ecological niche (Riley and Wertz, 2002). There is evidence that stress can lead to the induction of bacteriocins' production. For example, production of colicins (i.e., bacteriocins of $E$. coli) and several other bacteriocins of Gram-negative bacteria has been found to be stimulated during SOS response including the presence of mitomycin

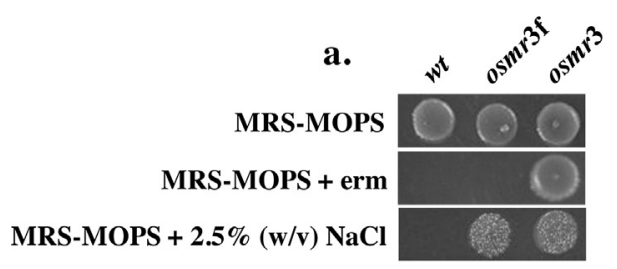

b.

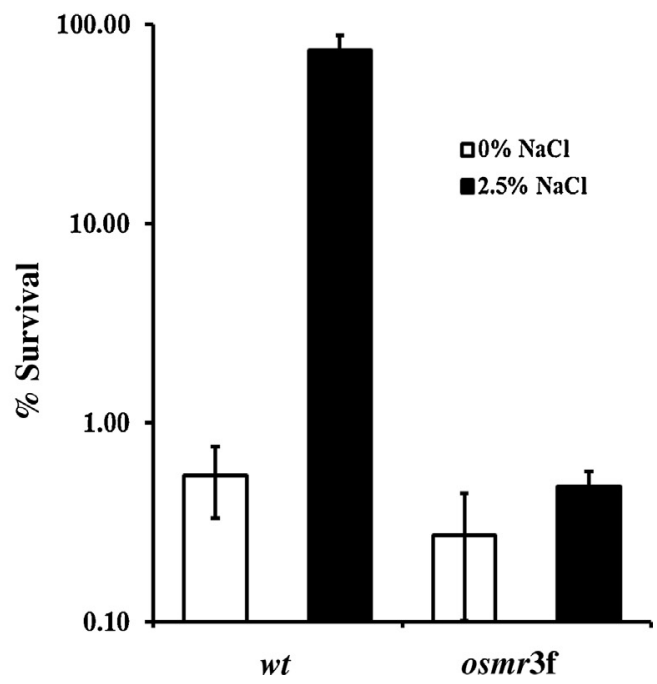

Fig. 5. Validation of the osmotic resistant phenotype of the S. macedonicus osmr3f markerless derivative of osmr3 mutant (a). Assessment of the ability of the osmr3f mutant to inhibit the outgrowth of $C$. tyrobutyricum spores under hyperosmotic conditions during co-culture in milk (b). Co-cultures of the $S$. macedonicus wild-type with $C$. tyrobutyricum spores in milk under iso-osmotic or hyperosmotic conditions were used as controls. The \% survival of $C$. tyrobutyricum cells was calculated against mono-cultures of the organism under identical conditions. The production of macedocin during co-cultures was also assessed by the well diffusion assay (data not shown).

$\mathrm{C}$, elevated temperatures, the depletion of nutrients and presumably all other stress conditions that can lead to the triggering of this response (Cascales et al., 2007; Gillor et al., 2008; Singh and Banerjee, 2008; Veselovskii et al., 2005). In Gram-positive bacteria a number of studies have been conducted investigating the effect of stressful conditions on the biosynthesis of bacteriocins. In some cases sub-optimal conditions were demonstrated to result in the over-production of bacteriocins (Anthony et al., 2009; De Vuyst et al., 1996; Delgado et al., 2007; Delgado et al., 2005; JimenezDiaz et al., 1993; Leal-Sanchez et al., 2002; Sashihara et al., 2001), while other stressful conditions had a negative effect on bacteriocins' production (Herranz et al., 2001; Himelbloom et al., 2001; Nilsen et al., 1998; Verluyten et al., 2004). These contradictory findings involve different producer strains or bacteriocins and distinct experimental frameworks, making it difficult to draw a clear conclusion about the correlation of stress conditions and bacteriocin production in Gram-positive bacteria including LAB. Apart from the sporadic works cited above, the potential negative influence of technological hurdles on the in situ production of bacteriocins in food matrices has not been addressed systematically even though it can prove to be a major disadvantage in the application of bioprotective cultures.

Osmotic stress developed by the addition of salt is one of the major stresses encountered by LAB during cheese making. In this study we demonstrated that the production of macedocin by $S$. macedonicus stops under hyperosmotic conditions. This inhibitory 
effect of $\mathrm{NaCl}$ has been observed with other bacteriocins, as well (Delgado et al., 2007; Herranz et al., 2001; Himelbloom et al., 2001; Nilsen et al., 1998; Verluyten et al., 2004). In contrast, the production of lacticin 481, which is phylogenetically related to macedocin, increased with increasing $\mathrm{NaCl}$ concentrations (Uguen et al., 1999). This difference between lacticin 481 and macedocin production under hyperosmotic conditions could be explained by the distinct production patterns reported for the two molecules. Lacticin 481 is produced in synthetic medium while macedocin is solely produced in milk. Furthermore, lacticin 481 was chosen as the prototype of this group of bacteriocins arbitrarily and its properties do not necessarily apply for all the members of the group. Macedocin's production stopped at $\mathrm{NaCl}$ concentrations well below those required for the inhibition of growth. In order to counteract this effect, we decided to follow a novel strategy, i.e., to manipulate $S$. macedonicus towards an osmotic stress resistant phenotype and to investigate whether this phenotype could result in the sustained production of macedocin under increased hyperosmotic conditions. Acquired robustness of LAB strains towards stressful conditions by means of food-grade genetic modifications has mainly focused on the improvement of their fermentation performance or their survival through the digestive tract (Bron et al., 2011; Upadrasta et al., 2011). In our case, in addition to the increased resistance to osmotic stress, mutated strains were examined regarding the effect of this phenotype on the production of macedocin.

In order to generate the osmr mutants in S. macedonicus, we used the lactococcal vector pGh9:ISS1 that has been employed in a number of LAB species beyond L. lactis like Streptococcus agalactiae, S. thermophilus and Streptococcus uberis (Kerro Dego et al., 2011; Spellerberg et al., 1999; Thibessard et al., 2002). We isolated three osmr mutants that were able to grow at higher $\mathrm{NaCl}$ concentrations compared to the wild-type. These conclusions are clearly supported by the assessment of the antimicrobial activity of the cell free supernatants and by their MS analysis. RT-PCR experiments revealed that abrogation of macedocin's production under hyperosmotic conditions in the wild-type is regulated at the transcriptional level. Interestingly, all osmr mutants retained their ability to produce macedocin at prohibiting for the wild-type $\mathrm{NaCl}$ concentrations by actively transcribing the macedocin's regulon. The production of macedocin at high $\mathrm{NaCl}$ concentrations by all osmr mutants (even those found disrupted in more than one chromosomal loci, data not shown) may suggest a generalized positive effect of the osmr phenotype on the bacteriocin's production. In other words, it could be hypothesized that the osmr mutants preserve a state of well-being at high $\mathrm{NaCl}$ concentrations allowing the production of macedocin. Under the same conditions the physiology of the wild-type could be severely affected, resulting in the abolishment of macedocin's production. The disrupted loci of the osmr mutants were identified and their involvement in the observed phenotypes has to be further assessed. This task is currently hindered due to the absence of tools for the genetic manipulation of S. macedonicus. Most importantly, the applicability of the markerless osmr3f mutant to effectively inhibit the outgrowth of $C$. tyrobutyricum spores in milk was demonstrated. The excision of the pGh9:ISS1 theoretically generates food-grade mutants (Maguin et al., 1996). If species within the Streptococcus bovis/Streptococcus equinus complex like $S$. macedonicus ultimately get approved to be used in foods (De Vuyst and Tsakalidou, 2008; Jans et al., 2013; Papadimitriou et al., 2014; Papadimitriou et al., 2012), then the osmr mutants could have interesting biotechnological applications in cheese manufacturing as engineered protective cultures. The strategy employed in this study could serve as a paradigm for the engineering of other $\mathrm{LAB}$, as well in order to improve their ability to produce bacteriocins in situ during food processing.
It should be noted that $S$. macedonicus may produce more than one bacteriocin. In the macedocin regulon $m c d A / m c d A$ í both code for macedocin, while $m c d A 1$ found directly downstream codes for a hypothetical bacteriocin not yet characterized. The three genes belong to the same operon and thus there is no reason to expect differential expression among them. The fact that $m c d A 1$ gene is third in the operon would not justify expression of $m c d A 1$ and not of $m c d A / m c d A i$. It is important to state that during the purification of macedocin the only major antimicrobial activity against $L$. lactis subsp. lactis LMG $6890^{\mathrm{T}}$ was related solely to this peptide (Georgalaki et al., 2002). Whether McdA1 is a functional bacteriocin and its antimicrobial spectrum remain to be investigated. Mass spectrometry analysis also supported that macedovicin, an additional lantibiotic of S. macedonicus (Georgalaki et al., 2013), is not produced in milk. We have also recently identified in silico three potential new bacteriocins in the genome of $S$. macedonicus (data not shown). However, we would like to highlight once more that macedocin's activity was the only antimicrobial activity against L. lactis $6890^{\mathrm{T}}$ we have observed in milk, so there is currently no reason to believe that those bacteriocins are active against $L$. lactis.

\section{Conclusions}

Bacteriocins of LAB are important antimicrobials for food preservation. Producer strains can be used for the in situ delivery of bacteriocins directly into the food matrices. However, technological stresses may interfere with the bacterial physiology and thus influence the production of bacteriocins. Engineering food-grade stress resistant mutants seems to be an appealing solution to secure bacteriocins' production under the stressful environment of food processing and storage. Osmotic stress negatively affects the production of macedocin by $S$. macedonicus but osmotic tolerant mutants can produce the bacteriocin even under hyperosmotic conditions. The relationship between genetically acquired stress resistance and bacteriocin production is not clear. Perhaps, the most obvious reason behind our observations is the fact that growth of S. macedonicus under hyperosmotic conditions is severely hindered compared to the osmr mutants. It is not uncommon for cells being under stressful conditions to shut down pathways that may not be directly implicated in survival. In fact, our RT-PCR results support attenuation of the transcription of the macedocin regulon in the wild-type strain under high $\mathrm{NaCl}$ concentrations. In contrast, transcription of the macedocin regulon is sustained in the osmr mutants under hyperosmotic conditions, which coincides with their ability to grow under these conditions. The actual reasons behind the production of macedocin under hyperosmotic conditions need further investigation. From a biotechnological point of view, we believe that we present solid evidence about the relationship of the osmotic resistant phenotype of S. macedonicus and the production of macedocin at hyperosmotic conditions. If mutants like osmr3f are finally approved for use, they may have important applications. Otherwise, construction of food-grade mutants according to current legislation is required. Production of macedocin by the osmr mutants in high salt concentrations will constitute in cheese an additional hurdle to high osmolarity for inhibiting salt resistant spoilage or pathogen microorganisms.

\section{Conflict of interest}

The authors declare that they have no conflict of interest. 


\section{Acknowledgement}

The present work was co-financed by the European Social Fund and the National resources EPEAEK and YPEPTH through the Thales project.

\section{References}

Altschul, S.F., Madden, T.L., Schaffer, A.A., Zhang, J., Zhang, Z., Miller, W., Lipman, D.J., 1997. Gapped BLAST and PSI-BLAST: a new generation of protein database search programs. Nucleic Acids Res. 25, 3389-3402.

Anastasiou, R., Aktypis, A., Georgalaki, M., Papadelli, M., De Vuyst, L., Tsakalidou, E., 2009. Inhibition of Clostridium tyrobutyricum by Streptococcus macedonicus ACA-DC 198 under conditions mimicking Kasseri cheese production and ripening. Int. Dairy J. 19, 330-335.

Anastasiou, R., Georgalaki, M., Manolopoulou, E., Kandarakis, I., De Vuyst, L. Tsakalidou, E., 2007. The performance of Streptococcus macedonicus ACA-DC 198 as starter culture in Kasseri cheese production. Int. Dairy J. 17, 208-217.

Anthony, T., Rajesh, T., Kayalvizhi, N., Gunasekaran, P., 2009. Influence of medium components and fermentation conditions on the production of bacteriocin(s) by Bacillus licheniformis AnBa9. Bioresour. Technol. 100, 872-877.

Baccigalupi, L., Naclerio, G., De Felice, M., Ricca, E., 2000. Efficient insertional mutagenesis in Streptococcus thermophilus. Gene 258, 9-14.

Beshkova, D., Frengova, G., 2012. Bacteriocins from lactic acid bacteria: Microorganisms of potential biotechnological importance for the dairy industry. Eng. Life Sci. 12, 419-432.

Bron, P., Bokhorst-van de Veen, H., Wels, M., Kleerebezem, M., 2011. Engineering robust lactic acid bacteria. In: Tsakalidou, E., Papadimitriou, K. (Eds.), Stress Responses of Lactic Acid Bacteria. Springer US, pp. 369-394.

Carolissen-Mackay, V., Arendse, G., Hastings, J.W., 1997. Purification of bacteriocins of lactic acid bacteria: problems and pointers. Int. J. Food Microbiol. 34 (1), 1-16.

Cascales, E., Buchanan, S.K., Duche, D., Kleanthous, C., Lloubes, R., Postle, K., Riley, M., Slatin, S., Cavard, D., 2007. Colicin biology. Microbiol. Mol. Biol. Rev. MMBR $71,158-229$.

Cotter, P.D., Hill, C., Ross, R.P., 2005. Bacteriocins: developing innate immunity for food. Nat. Rev. Microbiol. 3, 777-788.

De Vuyst, L., Callewaert, R., Crabbé, K., 1996. Primary metabolite kinetics of bacteriocin biosynthesis by Lactobacillus amylovorus and evidence for stimulation of bacteriocin production under unfavourable growth conditions. Microbiology 142, 817-827

De Vuyst, L., Tsakalidou, E., 2008. Streptococcus macedonicus, a multi-functional and promising species for dairy fermentations. Int. Dairy J. 18, 476-485.

Delgado, A., Arroyo Lopez, F.N., Brito, D., Peres, C., Fevereiro, P., Garrido-Fernandez A., 2007. Optimum bacteriocin production by Lactobacillus plantarum 17. 2b requires absence of $\mathrm{NaCl}$ and apparently follows a mixed metabolite kinetics. J. Biotechnol. 130, 193-201.

Delgado, A., Brito, D., Peres, C., Noé-Arroyo, F., Garrido-Fernández, A., 2005. Bacteriocin production by Lactobacillus pentosus B96 can be expressed as a function of temperature and $\mathrm{NaCl}$ concentration. Food Microbiol. 22, 521-528.

Franz, C.A.P., Holzapfel, W., 2011. The importance of understanding the stress physiology of lactic acid bacteria. In: Tsakalidou, E., Papadimitriou, K. (Eds.), Stress Responses of Lactic Acid Bacteria. Springer US, pp. 3-20.

Georgalaki, M., Papadelli, M., Chassioti, E., Anastasiou, R., Aktypis, A., De Vuyst, L., Van Driessche, G., Devreese, B., Tsakalidou, E., 2010. Milk protein fragments induce the biosynthesis of macedocin, the lantibiotic produced by Streptococcus macedonicus ACA-DC 198. Appl. Environ. Microbiol. 76, 1143-1151.

Georgalaki, M., Papadimitriou, K., Anastasiou, R., Pot, B., Van Driessche, G., Devreese, B., Tsakalidou, E., 2013. Macedovicin, the second food-grade lantibiotic produced by Streptococcus macedonicus ACA-DC 198. Food Microbiol. 33, 124-130.

Georgalaki, M.D., Van Den Berghe, E., Kritikos, D., Devreese, B., Van Beeumen, J., Kalantzopoulos, G., De Vuyst, L., Tsakalidou, E., 2002. Macedocin, a food-grade lantibiotic produced by Streptococcus macedonicus ACA-DC 198. Appl. Environ. Microbiol. 68, 5891-5903.

Gillor, O., Vriezen, J.A., Riley, M.A., 2008. The role of SOS boxes in enteric bacteriocin regulation. Microbiology 154, 1783-1792.

Herranz, C., Martinez, J.M., Rodriguez, J.M., Hernandez, P.E., Cintas, L.M., 2001. Optimization of enterocin P production by batch fermentation of Enterococcus faecium P13 at constant pH. Appl. Microbiol. Biotechnol. 56, 378-383.

Himelbloom, B., Nilsson, L., Gram, L., 2001. Factors affecting production of an antilisterial bacteriocin by Carnobacterium piscicola strain A9b in laboratory media and model fish systems. J. Appl. Microbiol. 91, 506-513.

Holo, H., Nes, I.F., 1989. High-frequency transformation, by electroporation, of Lactococcus lactis subsp. cremoris grown with glycine in osmotically stabilized media. Appl. Environ. Microbiol. 55, 3119-3123.

Jans, C., Follador, R., Hochstrasser, M., Lacroix, C., Meile, L., Stevens, M.J., 2013. Comparative genome analysis of Streptococcus infantarius subsp. infantarius CJ18, an African fermented camel milk isolate with adaptations to dairy environment. BMC Genomics 14, 200

Jimenez-Diaz, R., Rios-Sanchez, R.M., Desmazeaud, M., Ruiz-Barba, J.L., Piard, J.C. 1993. Plantaricins $S$ and T, two new bacteriocins produced by Lactobacillus plantarum LPCO10 isolated from a green olive fermentation. Appl. Environ. Microbiol. 59, 1416-1424.
Kerro Dego, O., Prado, M.E., Chen, X., Luther, D.A., Almeida, R.A., Oliver, S.P., 2011. pGh9:ISS1 transpositional mutations in Streptococcus uberis UT888 causes reduced bacterial adherence to and internalization into bovine mammary epithelial cells. Vet. Microbiol. 151, 379-385.

Khan, H., Flint, S., Yu, P.L., 2010. Enterocins in food preservation. Int. J. Food Microbiol. 141, 1-10.

Leal-Sanchez, M.V., Jimenez-Diaz, R., Maldonado-Barragan, A., Garrido-Fernandez, A., Ruiz-Barba, J.L., 2002. Optimization of bacteriocin production by batch fermentation of Lactobacillus plantarum LPCO10. Appl. Environ. Microbiol. 68 4465-4471.

Maguin, E., Prevost, H., Ehrlich, S.D., Gruss, A., 1996. Efficient insertional mutagenesis in lactococci and other Gram-positive bacteria. J. Bacteriol. 178, 931-935.

Nilsen, T., Nes, I.F., Holo, H., 1998. An exported inducer peptide regulates bacteriocin production in Enterococcus faecium CTC492. J. Bacteriol. 180, 1848-1854.

O'Sullivan, T.F., Fitzgerald, G.F., 1999. Electrotransformation of industrial strains of Streptococcus thermophilus. J. Appl. Microbiol. 86, 275-283.

Papadelli, M., Karsioti, A., Anastasiou, R., Georgalaki, M., Tsakalidou, E., 2007. Characterization of the gene cluster involved in the biosynthesis of macedocin, the lantibiotic produced by Streptococcus macedonicus. FEMS Microbiol. Lett. 272, 75-82.

Papadimitriou, K., Anastasiou, R., Maistrou, E., Plakas, T., Papandreou, N.C., Hamodrakas, S.J., Ferreira, S., Supply, P., Renault, P., Pot, B., Tsakalidou, E., 2015. Acquisition through horizontal gene transfer of plasmid pSMA198 by Streptococcus macedonicus ACA-DC 198 points towards the dairy origin of the species. PloS One 10, e0116337.

Papadimitriou, K., Anastasiou, R., Mavrogonatou, E., Blom, J., Papandreou, N.C., Hamodrakas, S.J., Ferreira, S., Renault, P., Supply, P., Pot, B., Tsakalidou, E., 2014 Comparative genomics of the dairy isolate Streptococcus macedonicus ACA-DC 198 against related members of the Streptococcus bovis/Streptococcus equinus complex. BMC Genomics 15, 272

Papadimitriou, K., Ferreira, S., Papandreou, N.C., Mavrogonatou, E., Supply, P., Pot B., Tsakalidou, E., 2012. Complete genome sequence of the dairy isolate Streptococcus macedonicus ACA-DC 198. J. Bacteriol. 194, 1838-1839.

Papadimitriou, K., Pratsinis, H., Nebe-von-Caron, G., Kletsas, D., Tsakalidou, E. 2007. Acid tolerance of Streptococcus macedonicus as assessed by flow cytometry and single-cell sorting. Appl. Environ. Microbiol. 73, 465-476.

Poirazi, P., Leroy, F., Georgalaki, M.D., Aktypis, A., De Vuyst, L., Tsakalidou, E., 2007. Use of artificial neural networks and a gamma-concept-based approach to model growth of and bacteriocin production by Streptococcus macedonicus ACA-DC 198 under simulated conditions of Kasseri cheese production. Appl. Environ. Microbiol. 73, 768-776.

Riley, M.A., Wertz, J.E., 2002. Bacteriocins: evolution, ecology, and application. Ann. Rev. Microbiol. 56, 117-137.

Sambrook, J., Fritsch, E.F., Maniatis, T., 1989. Molecular Cloning: A Laboratory Manual. Cold Spring Harbor Laboratory, Cold Spring Harbor, N.Y.

Sashihara, T., Dan, M., Kimura, H., Matsusaki, H., Sonomoto, K., Ishizaki, A., 2001. The effect of osmotic stress on the production of nukacin ISK-1 from Staphylococcus warneri ISK-1. Appl. Microbiol. Biotechnol. 56, 496-501.

Singh, J., Banerjee, N., 2008. Transcriptional analysis and functional characterization of a gene pair encoding iron-regulated xenocin and immunity proteins of Xenorhabdus nematophila. J. Bacteriol. 190, 3877-3885.

Spellerberg, B., Pohl, B., Haase, G., Martin, S., Weber-Heynemann, J., Lutticken, R., 1999. Identification of genetic determinants for the hemolytic activity of Streptococcus agalactiae by ISS1 transposition. J. Bacteriol. 181, 3212-3219.

Thibessard, A., Fernandez, A., Gintz, B., Decaris, B., Leblond-Bourget, N., 2002. Transposition of pGh9:ISS1 is random and efficient in Streptococcus thermophilus CNRZ368. Can. J. Microbiol. 48, 473-478,

Uguen, P., Hamelin, J., Le Pennec, J.P., Blanco, C., 1999. Influence of osmolarity and the presence of an osmoprotectant on Lactococcus lactis growth and bacteriocin production. Appl. Environ. Microbiol. 65, 291-293.

Upadrasta, A., Stanton, C., Hill, C., Fitzgerald, G., Ross, R.P., 2011. Improving the stress tolerance of probiotic cultures: recent trends and future directions. In: Tsakalidou, E., Papadimitriou, K. (Eds.), Stress Responses of Lactic Acid Bacteria. Springer US, pp. 395-438.

Van den Berghe, E., Skourtas, G., Tsakalidou, E., De Vuyst, L, 2006. Streptococcus macedonicus ACA-DC 198 produces the lantibiotic, macedocin, at temperature and $\mathrm{pH}$ conditions that prevail during cheese manufacture. Int. J. Food Microbiol. 107, 138-147.

Varani, A.M., Siguier, P., Gourbeyre, E., Charneau, V., Chandler, M., 2011. ISsaga is an ensemble of web-based methods for high throughput identification and semi-automatic annotation of insertion sequences in prokaryotic genomes. Genome Biol. 12, R30.

Verluyten, J., Messens, W., De Vuyst, L., 2004. Sodium chloride reduces production of curvacin A, a bacteriocin produced by Lactobacillus curvatus strain LTH 1174 originating from fermented sausage. Appl. Environ. Microbiol, 70, 2271-2278.

Veselovskii, A.M., Metlitskaia, A.Z., Lipasova, V.A., Bass, I.A., Khmel, I.A., 2005. Activation of the expression of the microcin C51 operon upon glucose starvation of cells at the exponential growth phase. Genetika 41, 48-52. 